\title{
An example of a protected area which has been opened to tourism: Tunca Valley Natural Park (NE Turkey)
}

\author{
Salih Birinci \\ Keywords: Tunca Valley, natural park, protected area, tourism
}

\section{Abstract}

Protected areas have great tourism potential thanks to their natural and cultural richness. For this reason, areas worldwide that are protected at various levels draw interest, and some have been opened to tourism. In this study, I examine the natural and social tourism potentials of Tunca Valley Natural Park in Turkey (established in 2013) and the types of tourist activities that could be developed there. The park attracts interest both for its natural features (rivers, glacial lakes, flora and fauna) as well as for its traditional settlements and culture. Various tourist activities, including physical activities, camping, wildlife observation and cultural tourism, could be developed within an integrated management plan in line with the principles of sustainable tourism.

\section{Profile}

Protected area

Tunca Valley

Natural Park

Mountain range

Altıparmak Mountains, Turkey

\section{Introduction}

Protected areas are defined as areas of land and sea managed via legislation and other means with the aim of protecting biodiversity and natural and cultural resources (IUCN 1994). Opening these areas to tourism and their sustainable usage have increased worldwide in recent years. However, the sustainable use of areas opened to tourism has sometimes failed to be included in management plans. Their usage must be based on ecological information, and effective management plans must be developed and implemented (Jurgens 1993). Within this context, there have been many scientific studies of protected areas which have emphasized the need to act in line with the principles of sustainable tourism when opening up protected areas to tourism (McCool 2009; Strickland et al. 2010; Newsome et al. 2013).

In recent years, protected areas have become some of the most popular tourist destinations (Walpole \& Goodwin 2001). Tourist activities in these areas are different from the other types of tourism in natural areas. Natural area tourism provides an alternative to traditional mass tourism, with the inclusion of adventure, nature-based, wildlife and eco-tourism (Newsome et al. 2002). For these reasons, recent studies related to protected areas have focused on eco-tourism, many researchers considering natural tourism or eco-tourism as a kind of sustainable tourism. In this context, protected areas are evaluated in terms of their possibilities for recreation and tourism, and of their natural and cultural resources (Stem et al. 2003; Ramutsindela 2004; Daniel et al. 2005; Rugendyke \& Son 2005; Trevor 2005).

In this study, I discuss the eco-tourism potential and sustainability of Tunca Valley Natural Park (NaP) in Turkey, which was opened to tourism without a management plan for tourism being made. Natural and cultural attractions of the $\mathrm{NaP}$ are identified, and I make suggestions for eco-tourism activities to be developed in line with sustainability.

\section{Study Area}

Tunca Valley NaP is located in northeastern Turkey, within the borders of Ardeşen town, on the Black Sea. The area was declared a $\mathrm{NaP}$ by the Ministry of Forestry and Water Affairs, General Directorate of $\mathrm{NaPs}$, in 2013, when it was taken under protection. The Park covers $40820 \mathrm{da}$ (decares) at altitudes ranging from 1400 to 3150 metres in the northern part of the Altıparmak Mountains (Figure 1).

The Altiparmak Mountains within the boundaries of the NaP reach 3300 m (e.g. Altıparmak (3301 m), Intorbaş $(3169 \mathrm{~m})$ and Şorakbaşı $(3118 \mathrm{~m}))$. In the northwestern part of the Park, the Göleteği, İntor and Şorak valleys, which run from west to east, were formed by glaciation. In the upper part of Göleteği valley, where slope values are extremely high, there are five glacial lakes, the largest of which are Lakes Sam and Göleteği. Other glacial lakes are Lakes Boravant, Ortasirtsal and Ortasirtsağ, in the main valley in the western part of the Park. In the eastern part of the Park, we find Lakes Hevek, Körgöl, Gürcü and Büyük Yayla (Gürgen 2009).

The NaP is located in the eastern Black Sea Region, which has the highest rainfall in Turkey; the climate shows oceanic features. In those parts of the area where rainfall is seen in every season and that are near the Black Sea, the average temperature is $13.9^{\circ} \mathrm{C}$, the average temperature of the coldest month is $5.5^{\circ} \mathrm{C}$ (February), and the average temperature of the hottest month is $23.4^{\circ} \mathrm{C}$ (August) (Data of the State Meteorology Affairs General Directorate 2014). The average humidity level is $75 \%$ and there are no significant dif- 


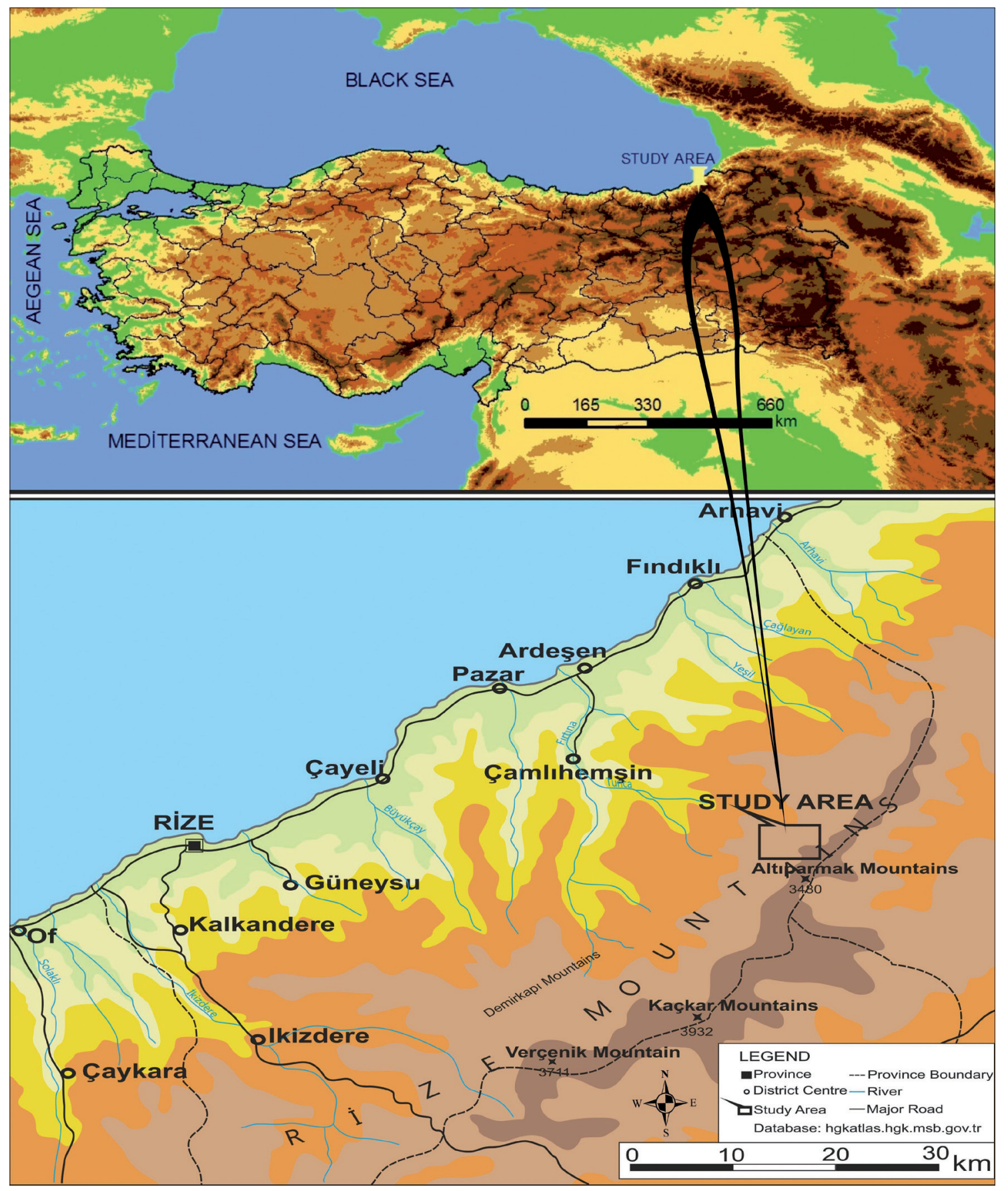

Figure 1 - Location of the study area.

ferences between the months. As the $\mathrm{NaP}$ ranges between $1400 \mathrm{~m}$ and over $3000 \mathrm{~m}$, there will be distinct differences in the climate conditions. The cool, moist, oceanic climate of the Coastal region changes rapidly above $2000 \mathrm{~m}$, where the average temperatures can drop to $6-8^{\circ} \mathrm{C}$; the higher parts of the $\mathrm{NaP}$ have a typical mountain climate. For this reason, people go to the higher altitudes in summer to escape the oppressive air in the coastal region. The same mountainous areas have started being used for tourism, where traditional transhumance is also practised.

The most important river within the $\mathrm{NaP}$ is the Tunca (Firtina basin). The river has its source in the glacial lakes in the high mountains (above $3300 \mathrm{~m}$ ) and joins the Firtına River near Ardeşen town centre, before draining into the Black Sea. There are many waterfalls along the Tunca, both within the boundaries of the NaP and outside them. Together with the waterfalls and the historical bridges, they are among the resources to be evaluated in terms of tourism.

The $\mathrm{NaP}$ and its surroundings are within the Colchic Flora part of the Euro-Siberian Phytogeography District and are among 200 ecological areas required to be protected by the World Wildlife Foundation (WWF). In addition, the Firtına Basin has been identified as one of the 25 most at-risk areas, ecologically, 


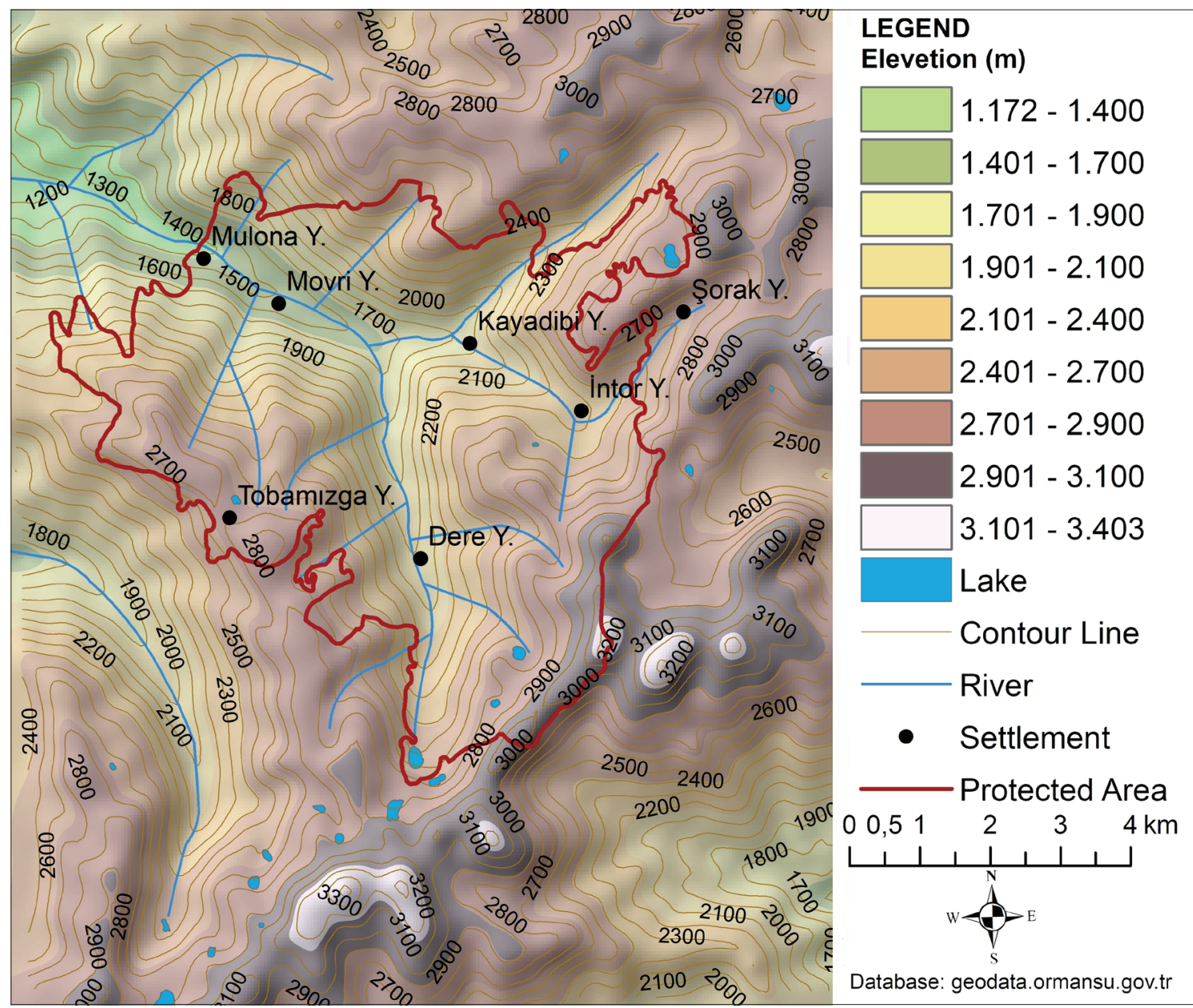

Figure 2 - Topography of the Protected Area.

by foundations such as Conservation International, the World Bank and the Global Environment Facility (GEF) (Kurdoğlu \& Akbulut 2015).

The eastern Black Sea mountains attract attention because of the diversity of their fauna. They are recognized as an important ornithological area because of the presence of the bearded vulture, griffon vulture, black vulture, golden eagle and black grouse (Yarar \& Magnin 1997). Due to these features, the Kaçkar Mountains where the $\mathrm{NaP}$ is located have been identified as one of Turkey's 100 most important nature and bird areas by the Wildlife Conservation Society and Bird Life International (Anonymous 2006). In terms of wildlife and birding in particular, the Park and its surroundings have an extremely high potential for eco-tourism.

Settlements within and around the $\mathrm{NaP}$ are mostly rural, the most important one being the settlement of Tunca. With a population of 2828 (TUIK 2015), this is the largest settlement in the Tunca valley. Within the boundaries of the $\mathrm{NaP}$, there are highland settlements and hamlets that are generally used only in summer. The traditional transhumance of cattle is carried out throughout the region. While some traditional seasonal settlements are no longer used during transhumance, others continue to be used in summer. In these settle- ments where a rural lifestyle continues, people live in environmentally friendly traditional housing.

One of the most important forms of tourism in the $\mathrm{NaP}$ and the surrounding area is mountain tourism. Mountaineering is an important activity in the glaciated valleys and among the highest peaks, especially in the Altiparmak Mountains (Somuncu 1989, 2011). Other activities carried out intensively in the Park include trekking, hiking and glacier climbing. The Trans Kaçkar, a long trekking route, lies within the park, running from the town of Ardeşen to the Tunca valley, via various plateaux, valleys and lakes (Gürgen 2009).

One of the most important attractions in the Park and its surroundings is plateau tourism. The plateaux attract domestic and foreign tourists for their natural beauty, clean air, traditional lifestyle, and the original architecture of the housing. The development of festivals on the plateaux in recent years has added to their attractiveness for tourists, who visit in increasing numbers. In this respect, Kayadibi, Dere, İntor, Movri and Mulano plateaux are the most important sites.

The surrounding areas of the NaP, such as Sirt and Tobomizga, have the potential to become sites for plateau tourism because of their natural beauty and cultural value. Tobomizga Plateau in particular, the lake near it and its floating islands stand out in terms of 
Table 1 - SWOT Analysis of the Tunca Valley Natural Park

\begin{tabular}{|c|c|}
\hline $\begin{array}{l}\text { Advantages } \\
\text { - Wealth of Natural Resources (glacial lakes, valleys, peaks, flora } \\
\text { and fauna diversity, climate) } \\
\text { - Cultural Resources (village and plateau settlements, traditional } \\
\text { housing, historic bridges, rural culture, traditional music and folk } \\
\text { dances, food culture peculiar to region, traditional clothing) } \\
\text { - Positive attitudes of local people towards tourism } \\
\text { - Conditions suitable for each activity (trekking, hiking), within the } \\
\text { scope of ecotourism } \\
\text { - Accessibility }\end{array}$ & $\begin{array}{l}\text { Disadvantages } \\
\text { - Lack of management plan } \\
\text { - Lack of promotion } \\
\text { - Lack of infrastructure (e. g. accommodation) } \\
\text { - Lack of trained staff } \\
\text { - Lack of awareness about protection }\end{array}$ \\
\hline $\begin{array}{l}\text { Opportunities } \\
\text { - Providing job opportunities for local people } \\
\text { - Protection of natural and cultural resources and transfer to future } \\
\text { generations } \\
\text { - Desire of local people to participate in the protection process }\end{array}$ & $\begin{array}{l}\text { Threats } \\
\text { - Increasing pressure on natural and cultural resources } \\
\text { - Environmental pollution } \\
\text { - Unplanned; management not suitable for protection of nature } \\
\text { - Lack of waste-disposal systems and infrastructure } \\
\text { - Perception of protected areas as tourist resources by local admin- } \\
\text { istrators }\end{array}$ \\
\hline
\end{tabular}

their ecology and potential for tourism (Bulut et al. 2010).

The Park and its surroundings offer rural tourism facilities and lifestyle (traditional villages and highland life), with traditional houses built of wood and stone, local traditions and customs, food and drink, and agriculture and livestock activities (Zaman 2008). Various attempts have been made in recent years to develop rural tourism; financial investment in particular rural settlements is important in terms of providing income for local people.

Thanks to its national importance for flora (including endemic species) and fauna (especially birds), the Park attracts ecotourism activities such as wildlife- and bird-watching, and botanic tourism. The Firtına basin offers water sports such as canoeing and rafting, as well as line fishing for sport (Zaman 2010). The Tunca River, which is too small for canoeing or rafting, also offers fishing, notably for natural brown trout.

As well as several ancient bridges over the Tunca River, the region's unique architecture, music, folk dances, clothing, food and traditional festivals all create cultural-tourism value. The Formulaz Festival (established in 2008) is one of the most important events for the domestic and international promotion of the Tunca valley. The wooden cart races attract many tourists, as do the traditional music and dance. The KaçkarAltuparmak (Sirt and Golezena) Plateau Festivals are also valuable in terms of attracting cultural tourism.

In addition, the area's natural beauty offers conditions for ecotourism activities, such as jeep safaris and mountain biking, while the high peaks, glacial lakes, waterfalls, natural fauna and traditional housing provide unique opportunities for photographers, whether individually or by taking part in a photo safari.

\section{Method}

The study aimed to reveal the current tourism values in the $\mathrm{NaP}$, and to identify values for future tourism from data obtained by qualitative research methods. Data for the park were digitized using the geographic information system (GIS) ArcGIS (10.3) and a database was created. After SWOT analysis and identifying the advantages and disadvantages of using the $\mathrm{NaP}$ for tourist activities, including opportunities and threats, I make suggestions regarding the potential of ecotourism and sustainable planning for the Park.

\section{Results and discussion}

As is the case worldwide, the importance of mass tourism to beach locations in Turkey has begun to decrease in recent years, and instead nature-based ecotourism activities are increasing. Excessive use of the environment and exceeding the carrying capacity of various locations through mass tourism has led to deterioration in some areas. As a result, there is a greater and greater focus on tourism that is sensitive to the environment and respectful of local people and cultures. Within this context, in areas that were largely untouched by tourism but which are rich in natural and cultural resources, various projects aimed at developing eco-tourism and nature-based tourist activities have seen a remarkable increase in the last 20 years. The area where this development has been greatest and taken place the fastest is the eastern Black Sea region, which also includes our research area.

In this region, several areas were given protected status or designated as tourist centres, by various statutes, due to their rich natural and cultural resources. However, since most of these areas were opened up for tourism without an integrated management plan, environmental degradation has occurred in some of them, just as it had done elsewhere because of mass tourism. Management plans must therefore be developed that will protect the natural environment and cultural structures in protected areas, preserving them for future generations. Master plans relating to such areas are vital in ecotourism planning, to avoid environmental degradation and to ensure that the principles of ecotourism are maintained (Cengiz 2007). Although it had been given protected status, the Tunca Valley $\mathrm{NaP}$ is one area that was opened up for tourism without any such management plan having been developed. 
Tunca Valley Natural Park attracts attention as an area for numerous ecotourism activities, including trekking, hiking, climbing; plateau, cultural and rural tourism; wildlife, birding and botanical tourism; river tourism, including fishing and water sports; photo and jeep safaris, and mountain biking and camping. Both domestic and foreign tourist numbers are constantly increasing. However, despite it being among the principles of ecotourism that the activities of ecotourism should provide local people with sufficient income, this is not the case. To help improve this situation, local people must be trained, and the traditional housing in rural settlements should be converted for use as hotels for visitors to the region. It is important, however, that local people should be made aware of the value of their traditional architecture, and care should be taken to avoid over-exploitation of areas neighbouring the protected areas themselves. Local people must be encouraged to construct new small-scale accommodation facilities which are in sympathy with the natural environment and in keeping with traditional architecture; the arrival of big entrepreneurs must be prevented.

The field work carried out in the $\mathrm{NaP}$ and interviews made with the visitors demonstrated that the $\mathrm{NaP}$ and its surroundings are rich in natural resources and attractive in cultural terms. These features are perceived as its foremost advantages. Other advantages are the positive attitude of local people towards tourism, accessibility by transportation, and the possibility of practising various ecotourism activities (Table 1).

Protection of the park area, including its natural and cultural resources, and evaluating these resources within the context of ecotourism provide emerging job opportunities for local people. Against such advantages are set the lack of a management plan, the inadequacy of the infrastructure, a lack of sensitivity to the need to protect the environment when the Park was opened up to tourism, and a lack of awareness regarding the need for sustainable tourism. The most important threats to the Park, meanwhile, are unplanned settlements to accommodate tourists, environmental pollution, and increased pressure on natural and cultural resources (Table 1).

Local festivals in the park and its surroundings (such as the Formulaz festival) are important both for the promotion of local culture to tourists and as opportunities for local people to come together. These festivals provide local people with a small amount of income through the sale of traditional crafts and food to visitors. However, the coexistence of many people in the festival areas leads to degradation in the soil and flora. For this reason, the locations of festivals within the protected area must be chosen very carefully, or must be outside the protected area altogether to prevent negative impacts on flora and fauna.

In the protected areas and Tunca Valley $\mathrm{NaP}$ in Turkey, the most serious problem is the lack of communication among the various management agencies (including those which manage tourism), other nongovernmental organizations, local people and tourists (Cengiz 2007). In opening protected areas up to tourism and developing rural areas, the ways that these might contribute to local people's income must be taken into consideration. From this perspective, tourist activities in the protected areas must be evaluated as themselves being tools for rural development, and sustainable tourism projects must be realized which respect a protection-usage balance.

\section{References}

Anonymous, 2006. Important natural areas in Turkey. Society for the Protection of Nature. Ankara.Turkey.

Bulut, I. \& H. Hadimli 2010. The floating islands and lakes in Koçdüzü Platou in northeast of Altıparmak Mountains. Standard Economic and Tecnical Journal 576: 92-101.

Cengiz, T. 2007. Tourism, an ecological approach in protected areas: Karagöl-Sahara National Park, Turkey. International Journal of Sustainable Development \& World Ecology 14(3): 260-267

Daniel, L., R. Manning \& D. Krymkowski 2005. The relationship between visitor-based standards of quality and existing conditions in parks and outdoor recreation. Leisure Sciences 27: 157-173.

Gürgen, G. 2009. Glacial Morphology of the northeast part of the Altıparmak mountains. Gazi University Journal of Gazi Educational Faculty 29(2): 311-331.

IUCN. 1994. Guidelines for Protected Area Management Categories. IUCN, Gland, Switzerland and Cambridge, $\mathrm{UK}$.

Jurgens, C.R. 1993. Strategic Planning for Sustainable Rural Development. Landscape and Urban Planning 27: 253-258.

Kurdoğlu, O. \& S. Akbulut 2015. An ecosystem that needs to be primarily protected in Turkey: valley of Kamilet and Durguna (Arhavi) and reasons of protection. Kastamonu University, Journal of Forestry Faculty 15(2): 279-296.

McCool, S.F. 2009. Constructing partnerships for protected area tourism planning in an era of change and messiness. Journal of Sustainable Tourism 17(2): 133-148.

Newsome, D., S.A. Moore \& R.K. Dowling 2002. Natural area tourism: ecology, impacts and management. Clevedon.

Newsome, D., S.A. Moore \& R.K. Dowling 2013. Natural area tourism: ecology, impacts and management. $2^{\text {nd }}$ edn. Clevedon.

Ramutsindela, M. 2004. Globalisation and nature conservation strategies in $21^{\text {st }}$-century Southern Africa. Tijdschrift voor Economische en Sociale Geografie 95: 61-72.

Rugendyke, B. \& N.T. Son 2005. Conservation costs: nature-based tourism as sevelopment at CucPhuong National Park, Vietnam. Asia Pacific Viewpoint 46: 185-200. 
Somuncu, M. 1989. The Kaçkar Mountains of the Eastern Black Sea Coast. Image of Turkey 26: 18-23.

Somuncu, M. 2011. Sustainable Development in the Eastern Black Sea Mountains: Present State and Perspectives. In: Zhelezov, G. (ed.), Sustainable development in mountain regions: southeastern Europe. New York: 215-225.

Stem, C.J, J.P. Lassoie, D.R. Lee, D. Deshler \& J.W. Schelhas 2003. Community participation in ecotourism benefits: the link to conservation practices and perspectives. Society and Natural Resources 16: 387-413.

Strickland-Munro, J. K., H.E. Allison \& S.A. Moore 2010. Using resilience concepts to investigate the impacts of protected area tourism on communities. $A n$ nals of Tourism Research 37(2): 499-519.

Trevor, M. 2005. Economic impacts of national park tourism on gateway communities: the case of Kosciuszko National Park. Tourism Economics 11: 247-259.

Walpole, M.J., H.J. Goodwin \& K.G.R. Ward 2001. Pricing policy for tourism in protected areas: lessons from Komodo National Park, Indonesia. Conservation Biology 15: 218-227.
Yarar, M. \& G. Magnin 1997. Important bird areas in Turkey. Society for the Protection of Nature (DHKD). Istanbul, Turkey.

Zaman, M. 2008. Significance of Firtına Stream Basin and Kaçkar Mountains National Park in terms of alternative tourism. Atatürk University Journal of Social Sciences Institute. 12(2): 1-33.

Zaman, M. 2010. Doğu Karadeniz. Kıyı Dağlarinda Dăg ve Yayla Turizmi. Erzurum: Atatürk University Publications, Turkey.

\section{Author}

\section{Salih Birinci}

is Assistant Professor at the Department of Geography, University of Atatürk, Turkey. He obtained an MSc in field geography in 2007 and PhD in 2013 from Atatürk University, where he has worked since 2005. His research interests focus on tourism, ecotourism, protected areas and settlement. Department of Geography, Faculty of Letters, Atatürk University, Erzurum, Turkey. E-mail: sbirinci6125@gmail.com 